\title{
Science and political power
}

\section{Susanne Heim, Carola Sachse, and Mark Walker: The Kaiser \\ Wilhelm Society under National Socialism. Cambridge: \\ Cambridge University Press, 2009, xxiv + 477 pp, US\$80.00 HB \\ David E. Rowe and Robert Schulmann: Einstein on Politics: \\ His Private Thoughts and Public Stands on Nationalism, Zionism, \\ War, Peace, and the Bomb. Princeton \& Oxford: Princeton \\ University Press, 2007, xxxiv + 523 pp, US\$29.95 HB}

\section{Charles Thorpe}

Published online: 4 August 2010

(C) The Author(s) 2010. This article is published with open access at Springerlink.com

The separation of knowledge from power has been central to the legitimation of western science; yet, science has been fundamental to the augmentation of modern state power, especially the perfection of the means of violence. There is a liberal, secular theodicy that asks 'if science is pure and universalistic, how is scientific evil possible?' How could liberal conceptions of the neutrality and purity of scientific knowledge be maintained in the face of the twentieth century's techno-scientific violence, from the development of chemical, biological, and nuclear weaponry to the involvement of Germany's scientific elite in the holocaust? The problem goes to a tension at the heart of liberal thought about rationality, science, and technology. The advance of value-free science is taken to be an essential motive force in the broader progress of human freedom and well-being. But value-freedom also means that there is no guarantee that technique will not instead augment the power of destruction.

Liberal thinkers have tended to present the relationship between science and destructiveness as arising from external political or ideological distortions. This has been a particular problem for the historical treatment of science in the Third Reich. The idea that scientists resisted, or that collaboration was unwilling, was important in the self-legitimation not only of the German scientific elite after the war, but also for American scientists and intellectuals concerned to present science as naturally allied with liberal democracy and opposing 'totalitarianism'.

The authors contributing to Susanne Heim, Carola Sachse, and Mark Walker's landmark reassessment, The Kaiser Wilhelm Society under National Socialism, challenge these liberal presuppositions: "The relationship between science and

C. Thorpe $(\bowtie)$

Department of Sociology, University of California, San Diego, 9500 Gilman Drive,

La Jolla, CA 92093-0533, USA

e-mail: cthorpe@ucsd.edu 
society should be seen not only in terms of politics influencing science, or even science influencing politics, but more with the two serving as mutual resources for each other" (p. 1). The book challenges the presumption of a conflict between science and National Socialism. Instead, it points to the "generous support" the Nazi regime offered to German science, the eagerness of Germany's scientific elite to draw on this support, and the willingness of German scientists to align their research to the Nazis' military and racial goals (p. 2). The Kaiser Wilhelm Society (KWS) "was an integral part of the National Socialist system of domination” (p. 4). "Pure science'," Wolfgang Schieder writes, "did not stand in opposition to National Socialist science policy in the war but was indeed one of its pillars" (p. 87).

In contrast to the assumption that Nazism held back scientific development, the authors argue that science under the Third Reich was exceptionally unconstrained. The use of human experimentation, intimately linked to the Nazis' program of genocide, was not something that was forced on scientists: "Instead, the Third Reich distinguished itself from democratic states in particular because it loosened, suspended, or eliminated ethical rules and controls on an unprecedented scale and thereby either allowed or encouraged scientists, engineers, and physicians to take advantage of unprecedented, often unethical, and sometimes murderous research opportunities" (p. 10). Science under Nazism was not science restrained but, in a certain sense, science unleashed.

The book presents the complexities of the politics of science under National Socialism, including chapters on forced scientific labor, human experimentation, brain research, aeronautics, chemical and nuclear weapons programs, and research supporting Nazi goals such as the occupation of Eastern Europe and the Soviet Union. The scientific elite negotiated their position within what Moritz Epple calls the "anarchistic" or what Schieder and Rüdiger Hachtmann call the "polycratic" state structure of National Socialism (pp. 32, 89, 285). The authors emphasize the active role of the scientific community in constructing alliances that would enable them to pursue their research agendas most effectively. They describe the complex couplings between scientific research agendas and Nazi political goals. Epple, for example, notes that the history of research at the Kaiser Wilhelm Institute for Fluid Dynamics showed a "remarkable absence of friction" between scientific and state goals (p. 310). Bernd Gausemeier notes that SS officer and agronomist Konrad Meyer, who shaped the regime's biological research policy, "did not expect vows of allegiance from his leading researchers but professional commitment in their domain." The link between 'pure' botany and breeding research (promoted by the autarky policy) "was not a development imposed on science by politics but rather resulted from experimental possibilities that were furnished with a certain political meaning by the scientists themselves" (pp. 231, 249). Schieder suggests that the polycratic political order of Nazism resulted in "an entirely new latitude" that scientists "were able to use to their advantage" (p. 89). And indeed the lack of ethical restraint created avenues for research. As Hans-Walter Schuml notes in his study of the close interaction between the professional ideology of psychiatry and the eugenic and euthanasia policies of the Nazis, the murder of patients with mental illnesses and mental disabilities "opened up new possibilities for psychiatric research" (p. 109). 
The "lack of friction" between science and Nazism also becomes understandable when one considers scientists as part of the German bourgeoisie. Hachtman argues that "When scientific and nonscientific employees of the KWS expressed often enthusiastic approval of the 'national awakening' in late January 1933, they were thus part of the bourgeois mainstream" (p. 27). The Nazi rise to power "was accompanied by a chorus of especially bourgeois and middle-class approval" (p. 26). Nazi re-militarization and the rhetoric of rebuilding national greatness were particularly appealing, Hachtman notes, to scientists at the Kaiser Wilhelm Society, which was closely tied to imperial traditions (p. 28). The Nazi seizure of power meant that KWS scientists who had been involved in covert military work could now engage in such work openly (pp. 28-29).

If the political attitudes of KWS scientists were typical of the German middle class by the beginning of the 1930s, this can be interestingly contrasted with the political outlook of Albert Einstein as detailed in David Rowe and Robert Schulmann's exhaustive edited collection, Einstein on Politics. For Einstein's politics was also typically middle class. One could say that Einstein was militantly middle class, but his was a middle-class outlook deriving from an earlier period. It had been more widely superseded by the nationalist orientation described by Hachtman (see Elias, 1996: 136). Einstein's distinctly anti-political politics, his hostility to militarism, and his valorization of culture and intellectual life as against the state can be traced to the particular habitus of the German middle class that took shape from the 18th into the 19th century, before giving way to nationalism, a "romanticization of power," and a militaristic cult of hardness and ruthlessness in the period after 1871 (Elias, 1996: quoting 181, see also 134-154, 204-206). This transformation of middle-class habitus, set out in Norbert Elias's study The Germans, I believe holds the key to understanding Einstein's politics as detailed in Rowe and Schulmann's book. Elias writes:

For many members of the educated German middle classes, 'culture' continued to represent a realm of retreat and of freedom from the unsatisfactory pressures of a state which accorded them the position of second-class citizens by comparison with the privileged nobility and denied them access to most of the leading positions in the state... Withdrawal into the non-political realm of culture made it possible for them to maintain an attitude of reserve, often highly critical reserve, towards the existing order without embarking on any active opposition to the regime itself (Elias, 1996: 127-128).

This kind of "withdrawal" into an apolitical cultural orientation characterized Einstein's youthful attraction to solitude and a view of science as an escape from the cares of the everyday world. This was the meaning of Einstein's famous image of the scientist as a lighthouse keeper (p. 280; see also Schweber 2008: 6). A typical quotation: "in spite of the troubling, disgusting war I work quietly in my room" (p. 61). That solitude was, in part, an expression of distaste for the militarist culture of the German imperial state. In his aloofness from politics, and his valorization of culture, Einstein reflected a middle-class orientation that had been more typical during the 19th century (Elias 1996: 136). Einstein was representative of that portion of the middle class that retained these earlier sentiments. He was, in that 
way, also characteristically German-Jewish. Historian George Mosse has argued that the middle-class identification with cultural values was embraced particularly intensely by German Jews. While the majority of the German middle class turned from classical notions of Bildung toward romantic nationalist ideas of Volk culture, the German-Jewish middle class "clung to the older concept of Bildung" (Mosse 1985: 69). Einstein himself identified Jews as carriers of Enlightenment values: "The striving after knowledge for its own sake, the love of justice... and the quest for personal independence-these are the motivating traditions of the Jewish people" (p. 320). He suggested that anti-Semitism expressed a hatred for freethought, rooted in a revolt of the passions against reason (pp. 315, 321-23).

Einstein's outlook expressed what Elias called the "non-political, if not antipolitical and humanist, implications of the concept of culture" (Elias 1996: 129). But Einstein turned this overtly apolitical valorization of culture into a basis for political engagement - a politics that had a distinctly anti-political character. It is of great significance that Einstein's key break from a totally apolitical cultural orientation, and the start of his engagement with public issues came during World War One but especially in the early years of the Weimar Republic. As Rowe and Schulmann say, "It was under these circumstances that Einstein found his voice, decisively ended his seclusion, and joined the political fray" (p. 4). Einstein's political involvement coincided with the end of imperial Germany and the creation of an institutional basis for the emergence of the German middle class out from under what had been the domination of the state by the nobility (p. 81, 93). In contrast to many middle-class Germans who remained hostile to the Republic, Einstein embraced the Weimar Republic and became an international symbol of it. For this, he was targeted by rightwing assassins.

Einstein continued to hold onto an "ascetic, idealized image of the scientists' realm” (p. 26), in Rowe and Schulmann's words, but he increasingly explicitly set this other-worldly role in opposition to the powers of the world. This was expressed politically in Einstein's intense, lifelong hostility to militarism and military establishments. Military organization, in his view, embodied an animalistic "herd life" (Einstein 1982: 10). Elias argues that middle-class moralism contrasted sharply with the Machiavellian realism that characterized inter-state relations and which reflected aristocratic codes. The middle-class code was one "of virtue rather than of honour" (Elias 1996: 139). It was characteristic of the German middle-class conception of morality that it was universalistic, general, and abstract. The demands of morality were experienced as deriving from "an eternal absolute" (Elias 1996: 140). Einstein's politics were a counterposing of both culture and morality to 'realist' power-politics. This opposition framed his lifelong assertion of a special role for intellectuals in public life as carriers of truth and of universal values, and a view of the special obligation of intellectuals to oppose violence (pp. 420-21, 428-433). Einstein consistently emphasized the primacy of morality, conceived of as a universal law, over and against the 'realist' strategies of states. Einstein asserted that "The State exists for man not man for the State" (p. 51).

While Rowe and Schulmann show Einstein's engagement with the political events and problems of his day, there is the sense that Einstein treated such events in the world as opportunities to apply or enunciate general ahistorical moral truths, or 
what he called "those supreme and everlasting values" (p. 281). The editors note that "he generally preferred to address a problem in abstract terms that embraced many different situations rather than dwell on the specific conditions that pertain in one country at a particular time" (p. 54). This abstractness of his moral and political thought often, however, tended toward a certain flatness and predictability in his pronouncements. The aphoristic character of Einstein's political statements could tend toward a rather simplistic moralism (p. xx). Einstein's thought often resolved itself into Enlightenment antinomies: individualism vs. collectivism or reason vs. the passions. Despite his emphasis on universal moral values, Einstein wrote, "I know that it is a hopeless undertaking to debate about fundamental value judgments. For instance, if someone approves, as a goal, the extirpation of the human race from the earth, one cannot refute such a viewpoint on rational grounds" (p. 433). The aphoristic character of Einstein's moral pronouncements perhaps followed from this notion that that they could not be fruitfully argued for-one accepted them or one did not. But such an acceptance of the fundamental irrationality of value positions was surely a problem for a thinker who desired a strong role for both humanist morality and rationality in public life.

The relationship between abstract Kantian moral principles and the concrete world translated, for Einstein, into a question of where in the world, in what country, those principles would find a locus: "I will only stay in a country where political liberty, tolerance, and equality of all citizens before the law prevail" (p. 54). 'Civilization' was a key word for Einstein and he conceptualized it as a locus of the moral principles to which he adhered. He framed his political arguments as appeals to "the conscience of the civilized world" (p. 425) or the need to "save European civilization" (p. 283). Yet the assumption that Europe was the seat of 'civilization' was called into question by the destruction of the Weimar Republic and the rise of the Nazis. In 1935, Einstein stated that the Nazi atrocities reflected "no credit on the community of nations which calls itself civilized!" (p. 294). Although in the 1930s Einstein publicly praised American political freedoms, even that early assessment was ambivalent (pp. 55, 242-246), and he became increasingly critical of America's commercialism, economic inequality, and militarism. By 1938 he said "I don't give a farthing more for Europe's future. America joined boldly in the strangulation maneuver against Spain. Here too [the USA] in fact money rules..." (p. 311). Whereas in 1930, Einstein had suggested that America was charged by "destiny" with a struggle against militarism (p. 239), by the 1950s he was a vocal critic of the militarization of American society, and the development within the United States of a paranoid police state (p. 403).

The tensions between Einstein's attachment to abstract values transcending time and space and his search for a locus for these values in the world also informed his Zionism. He tried to reconcile his commitment to Zionism with his internationalism, but his attempts to do so appear strained and there was, to say the least, a high degree of tension between these aspects of his political thought (pp. 1-2, 137). Einstein's anti-political cultural orientation was reflected in his specifically cultural Zionism. While he supported a Jewish cultural settlement in Palestine, he explicitly opposed the goal of forming a Jewish nation state and he was set especially adamantly against the idea of a militarized Jewish state (pp. 268, 355). Einstein 
quickly realized the fallacy of the early Zionist slogan that Palestine was a "land without people for a people without land" (p. 30) and consistently called for reconciliation with the Palestinian Arabs. However, his argument for Zionism did rely on the colonialist discourse of a civilizing mission. The Jews would bring science to the Middle East and would modernize and improve the land and the living conditions of the population (p. 331). Hostility to Jewish settlement was, he suggested, just rooted in the Arab ruling class's opposition to this modernization (p. 329). He could reconcile Zionism with internationalism by viewing the former as a moral and cultural movement, charged with a mission of social uplift. But this view quickly came into contradiction with the development of Zionism as an actual political movement (e.g., p. 350). Just as Einstein had in 1919 appealed to the "public conscience" of the Germans against calls for the expulsion of East European Jews (p. 141), he later appealed to the Israelis' moral self-image: "The attitude we adopt toward the Arab minority will provide the real test of our standards as a people" (p. 505). The appeal to morality against realpolitik was central to Einstein's thought and conditioned his hope for peaceful coexistence of Jews and Arabs in Palestine, though he was aware of the growing fragility of these hopes. Einstein's insistence on non-militarization and non-alignment clearly ran counter to Israel's subsequent development as a techno-military power aligned with US hegemony.

The editors' discussion of Einstein's socialism hedges this with all sorts of caveats that seem to me unnecessary. They qualify the discussion of Einstein's socialism with the insistence that he "placed equal if not more importance on the traditional liberal goal of self-realization of the individual" (p. 49). But this misses the crucial point that it was precisely Einstein's liberal commitments that drove him, over time, toward socialism. For he came to see individualism as stunted unless joined with social cooperation and he saw the "crippling of the social consciousness of individuals" as being "the worst evil of capitalism" (pp. 443, 445). This was the crucial historical movement of Einstein's thought. The conflict between his abstract Enlightenment ethical ideals and the historical reality of European and American militarism, which he came to see as intimately related to the capitalist concentration of economic power, drove his thought in a direction that was utopian. "Socialism, as I understand it," he wrote, "does not exist anywhere today" (p. 454). In his 1949 statement for the Monthly Review, he imagined the "socialist society of the future" as the fulfillment of an emerging "planetary community" (pp. 440, 443). Einstein's political thought can be understood in terms of a dynamic tension between his adherence to highly abstract, transcendent ideals, and his active involvement in history. His ideals could not be realized in any place in the present, therefore only in a conception of the future.

Einstein's conception of a future that could be radically different from the present also justified thinking beyond narrowly technical or instrumental forms of reason. So he asserted that he had a right to speak out on the need for socialism even though he was "not an expert on economic and social issues": "Since the real purpose of socialism is precisely to overcome and advance beyond the predatory phase of human development, economic science in its present state can throw little light on the socialist society of the future" (pp. 439-440). It was essential, in Einstein's 
worldview, that reason should guide human relations. But this form of reason had to be of a different kind than purely technical rationality. In a message for the Peace Congress of Intellectuals at Wroclaw in 1948, Einstein said: "By painful experience we have learned that rational thinking does not suffice to solve the problems of our social life. Penetrating research and keen scientific work have often had tragic implications for mankind... introducing a grave restlessness into his life, making him a slave to his technological environment, and-most catastrophic of allcreating the means for his own mass destruction". Opposing the scientization of violence was, Einstein argued, an essential duty of the modern scientist: "We scientists, whose tragic destination has been to help in making the methods of annihilation more gruesome and more effective, must consider it our solemn and transcendent duty to do all in our power in preventing these weapons from being used for the brutal purpose for which they were invented" (Einstein 1982: 148). This moral duty required moving beyond a narrowly technical role toward the intellectual formulation of "a social-ethical end" (p. 440).

Open Access This article is distributed under the terms of the Creative Commons Attribution Noncommercial License which permits any noncommercial use, distribution, and reproduction in any medium, provided the original author(s) and source are credited.

\section{References}

Einstein, A. 1982. Ideas and opinions. New York: Crown.

Elias, N. 1996. The Germans. New York: Columbia University Press.

Mosse, G.L. 1985. German Jews beyond Judaism. Bloomington: Indiana University Press.

Schweber, S. 2008. Einstein and Oppenheimer: The meaning of genius. Cambridge, MA: Harvard University Press. 